\title{
Epidemiological and pathological aspects of noninfectious diseases of the gastrointestinal tract in 114 horses in Southern Brazil ${ }^{1}$
}

\author{
Matheus V. Bianchi² (D), Paula R. Ribeiro ${ }^{2}$ (D) Alanna S. Stolf $^{2}$, Marianna Bertolini² \\ Cláudio J.M. Laisse ${ }^{2}$ (D) , Luciana Sonne ${ }^{2}$ (D) David Driemeier $^{2}$ (D) and Saulo P. Pavarini ${ }^{2 *}$ (D)
}

ABSTRACT.- Bianchi M.V., Ribeiro P.R., Stolf A.S., Bertolini M., Laisse C.J.M., Sonne L., Driemeier D.
\& Pavarini S.P. 2020. Epidemiological and pathological aspects of noninfectious diseases
of the gastrointestinal tract in 114 horses in Southern Brazil. Pesquisa Veterinária
Brasileira 40(4):242-253. Setor de Patologia Veterinária, Faculdade de Veterinária, Universidade
Federal do Rio Grande do Sul, Av. Bento Gonçalves 9090, Porto Alegre, RS 91540-000, Brazil.
E-mail: saulo.pavarini@ufrgs.br

Equine colic is one of the most common cause of death in horses, but few studies have investigated specifically the conditions at the necropsy. This study aimed to describe the epidemiological and pathological features of noninfectious diseases of the gastrointestinal tract in horses. A retrospective study was conducted in search of cases of these diseases affecting horses from 2005 to 2017. During this period, 114 horses died of noninfectious diseases of the gastrointestinal tract, and the main causes were: primary gastric dilation $(27 / 114)$, volvulus (27/114), enterolithiasis (20/114), rectal (colonic) perforation $(15 / 114)$, gastric or cecocolonic impaction (10/114), incarcerations (6/114), intussusception (4/114), and others (5/114). Mixed breeds horses (56/114) and males (69/114) were mostly affected. The horses had a median and mean age of 10 and 10.9-years old, respectively. Primary gastric dilation was characterized by distension of the stomach by moderate to large amounts of content, which in 21 cases caused tearing of the stomach wall at the greater curvature (peritonitis), and the main predisposing factor was alimentary overload (17/27). Intestinal volvulus occurred within the small intestine (14 cases) and within the large intestines (13 cases). Grossly, there was intestinal ischemia with reddened to deep-black serosa and diffusely red mucosae. Enterolithiasis caused partial or complete obstruction of the right dorsal colon $(9 / 20)$, transverse colon $(4 / 20)$, small colon and right dorsal colon $(3 / 20)$, rectum and right dorsal colon $(2 / 20)$, and small colon $(2 / 20)$. Viscera perforation and peritonitis occurred in 11 cases. Rectal (colonic) perforation involved the rectum (10/15), rectum/small colon $(4 / 15)$, and the small colon (1/15). It was characterized by a focally extensive transmural tearing, associated with reddened borders, and retroperitoneal to diffuse peritonitis. Palpation related iatrogenic injuries $(11 / 15)$ were the main cause. Impactions affected the large colon $(7 / 10)$, the cecum $(2 / 10)$, and the stomach $(1 / 10)$. Incarcerations consisted of inguinoscrotal hernias $(2 / 6)$, small intestine entrapment by a mesenteric failure $(2 / 6)$, diaphragmatic hernia, and umbilical eventration. Grossly, the organs were constricted by a hernial ring, with intestinal ischemia and reddened to dark-red serosa. Predisposing factors included previous surgeries $(2 / 6)$ and patent inguinal ring (1/6). Intussusception involved the small intestine (3/4) and ileocecum (1/4). Foals with lack of colostrum intake and concomitant pneumonia was a characteristic presentation (3/4). Grossly, the intussusceptum slipped into intussuscipiens, with diffuse deep black-red discoloration. Other causes included large

\footnotetext{
${ }^{1}$ Received on October 8, 2019.

Accepted for publication on October 20, 2019.

${ }^{2}$ Setor de Patologia Veterinária, Faculdade de Veterinária, Universidade Federal do Rio Grande do Sul (UFRGS), Avenida Bento Gonçalves 9090, Agronomia, Porto Alegre, RS 91540-000, Brazil. *Corresponding author: saulo.pavarini@ufrgs.br
} 
colon displacement (2/5), extrinsic and intrinsic obstruction of the small intestine (2/5), and an intestinal adenocarcinoma. Noninfectious gastrointestinal diseases are major causes of death in horses. Epidemiological and gross features of the conditions should be accounted to obtain a final diagnosis of the cause of the colic.

INDEX TERMS: Epidemiology, pathology, noninfectious diseases, gastrointestinal tract, horses, Brazil, colic, gastric dilation, volvulus, enterolithiasis, rectal perforation, impaction, incarceration, intussusception.

RESUMO.- [Aspectos epidemiológicos e patológicos de
doenças não infecciosas do trato gastrointestinal de 114
equinos no sul do Brasil.] A cólica em equinos é considerada
como a principal causa de morte de cavalos, porém poucos estudos têm investigado especificamente as condições envolvidas através da necropsia. $\mathrm{O}$ objetivo desse estudo foi descrever os aspectos epidemiológicos e patológicos de doenças não infecciosas do trato gastrointestinal de equinos. Foi conduzido um estudo retrospectivo em busca de casos dessas doenças envolvendo cavalos de 2005 a 2017. Durante esse período, 114 equinos morreram devido a doenças não infecciosas do trato gastrointestinal, e as principais causas foram: dilatação gástrica (27/114), vólvulos $(27 / 114)$, enterolitíase (20/114), ruptura retal (colônica) (15/114), compactação gástrica ou cecocolônica (10/114), encarceramentos (6/114), intussuscepções (4/114), e outros (5/114). Animais sem raça definida (56/114) e machos (69/114) foram mais afetados. Os equinos apresentavam uma média e mediana de idade de 10 e 10,9 anos, respectivamente. A dilatação gástrica primária era caracterizada por distensão do estômago por moderada a grande quantidade de conteúdo, que em 21 casos provocava ruptura da parede gástrica na curvatura maior (peritonite), e o principal fator predisponente foi sobrecarga alimentar (17/27). Vólvulo intestinal ocorreu no intestino delgado e no intestino grosso (14 e 13 casos, respectivamente). Macroscopicamente, havia isquemia intestinal com serosa avermelhada a enegrecida e mucosa difusamente avermelhada. A enterolitíase causou obstrução parcial ou completa do cólon dorsal direito $(9 / 20)$, cólon transverso $(4 / 20)$, cólon menor e cólon dorsal direito $(3 / 20)$, cólon menor $(2 / 20)$, e reto e cólon maior direito $(2 / 20)$. Perfuração de vísceras e peritonite foram observadas em 11 casos. A ruptura retal (colônica) envolveu o reto $(10 / 15)$, reto/cólon menor $(4 / 15)$ e cólon menor $(1 / 15)$. Essa era caracterizada por ruptura transmural focalmente extensa, com bordos avermelhados e peritonite retroperitoneal a difusa. Traumas relacionados à palpação (11/15) foram a principal causa. Compactações afetaram o cólon maior $(7 / 10)$, ceco $(2 / 10)$ e estômago (1/10). Encarceramentos consistiram em hérnias inguinoescrotais $(2 / 6)$, encarceramento de alças intestinais por falha no mesentério $(2 / 6)$, hérnia diafragmática e eventração umbilical. Macroscopicamente, os órgãos estavam constritos por um anel hernial, com isquemia intestinal e serosa avermelhada a vermelho-escura. Fatores predisponentes incluíram cirurgias prévias (2/6) e anel inguinal patente (1/6). Intussuscepções envolveram o intestino delgado (3/4) e íleoceco (1/4). A apresentação característica foi em potros com falta de colostro e concomitante pneumonia. Macroscopicamente, o intussuscepto deslizava em direção ao intussuscepiente, exibindo coloração vermelho-enegrecida difusa. Outras causas incluíram deslocamento de cólon maior $(2 / 5)$, obstrução extrínseca e intrínseca do intestino delgado $(2 / 5)$, e um caso de adenocarcinoma intestinal. Doenças não infecciosas são importantes causas de morte em equinos. Os aspectos epidemiológicos e macroscópicos das condições devem ser considerados para o que o diagnóstico final da causa da cólica seja obtido.

TERMOS DE INDEXAÇÃO: Epidemiologia, patologia, doenças não infecciosas, trato gastrointestinal, equinos, Brasil, cólica, dilatação gástrica, vólvulo, enterolitíase, ruptura retal, compactação, encarceramento, intussuscepção.

\section{INTRODUCTION}

Horses are monogastric grazers, with a gastrointestinal tract that may be divided into three segments: foregut (stomach and esophagus), midgut (small intestine), and hindgut (large colon and cecum). The foregut and midgut receive continuous amounts of food that finally reach the hindgut, which is, essentially, a fermentation chamber. However, modern management practices have replaced the horse's natural grazing habit with a diet high in grains and fats, which may not be properly digested (Bland 2016). Colic is an acute gastrointestinal disease characterized by a clinical syndrome of abdominal pain in horses, which can be infectious or noninfectious (Tinker et al. 1997). Almost 10 to $11 \%$ of horses will present clinical signs of colic at some point in their lives, and mortality rates are usually high (Bland 2016). Surgical intervention is sometimes necessary to treat colic in horses when a noninfectious cause is defined, but this is expensive, extremely invasive, and has a relatively high postoperative mortality rate (Immonen et al. 2017, Mair \& Smith 2005a, Proudman et al. 2002).

Colic has been considered the most common cause of death in horses, accounting for at least $28 \%$ of deaths (Tinker et al. 1997). Numerous studies have described the alimentary system as the most commonly involved in the cause of death of horses, followed by the locomotor, nervous, cardiovascular, and respiratory systems (Baker \& Ellis 1981, Pierezan et al. 2009, USDA 2017). Most studies have listed the noninfectious diseases of the alimentary tract in horses (Baker \& Ellis 1981, Pierezan et al. 2009, Marcolongo-Pereira et al. 2014), but few have specifically investigated its conditions, focusing on the epidemiological and pathological features. Nonetheless, nonspecific colic cases (unknown causes) are often clinically referred to as spasmodic, flatulent, or mild colic, especially because of lack of proper surgery or necropsy (Tinker et al. 1997).

The knowledge of common causes and outcomes of equine colic may aid veterinarians to consider appropriate diagnostic methods, therapeutics, and determine the prognosis for the individual horse (Voigt et al. 2009). Furthermore, equine colic might have a substantial economic impact, as sport or reproductive horses are becoming more valuable, and insurance expenses have increased. In 2001, by instance, the United States horse insurance industry paid over US\$ 115 
million in claims due to horse's deaths (Bland 2016). With current trends of insuring horses in Brazil, this knowledge is becoming increasingly important, as insurance companies may need detailed necropsy reports into the cause of death in order to reimburse the horse owner (Immonen et al. 2017). Therefore, this study aimed to describe the epidemiological and pathological features of noninfectious diseases affecting the gastrointestinal tract in 114 horses necropsied in Southern Brazil.

\section{MATERIALS AND METHODS}

A retrospective study of noninfectious diseases affecting the gastrointestinal tract of horses was conducted at the necropsy database of the veterinary pathology laboratory from January 2005 to December 2017. All horses were from properties located in the state of Rio Grande do Sul, especially in the metropolitan region of Porto Alegre. The necropsy protocols were reviewed, and information regarding the cause of death, predisposing factors (one or multiple per horse), location of lesions, breed, age (age range, mean and median age), and sex were registered. Gross lesions were reevaluated through photographs and combined with the previous descriptions available on the necropsy reports. The cases were grouped into categories: primary gastric dilation, volvulus, enterolithiasis, rectal (colonic) perforation, gastric or cecocolonic impaction, incarceration, and intussusception. Displacements, extrinsic obstruction, intrinsic obstruction, and neoplasm did not fit into any of the above categories, and, thus, were listed as other causes. Each category was later evaluated in terms of secondary gastrointestinal abnormalities, such as ruptures, peritonitis, gastric dilation, and impactions. Additionally, enteroliths were classified according to location, aspect, distribution (single or multiple), and composition of the central nidus (foreign body that originated the enterolith). Furthermore, the causes of rectal (colonic) perforation were characterized as iatrogenic (reproductive tract or colic related palpation) or natural mating. As gross lesions were characteristic of many of these categories, histological features (stained with hematoxylin and eosin, HE) were reevaluated only for the neoplasm.

\section{RESULTS}

From January 2005 to December 2017, 654 horses were necropsied in the veterinary pathology laboratory. The alimentary system was related to the cause of death in 201 horses, of which 114 (56.7\%) were associated with noninfectious diseases of the gastrointestinal tract. These included mainly gastric dilation (27 cases), volvulus of the small or large intestines (27 cases), enterolithiasis (20 cases), rectal (colonic) perforation (15 cases), gastric or cecocolonic impaction (10 cases), incarcerations or hernias (six cases), intussusception (four cases), and other causes (five cases). Mixed breed horses were mostly affected (56/114), followed by Criollo breed (32/114), Ponies (6/114), Quarter Horse (5/114), Brazilian Sport Horse or "Brasileiro de Hipismo" (5/114), Thoroughbred (5/114), American Trotter (2/114), and Appaloosa, Dutch Warmblood, and Brazilian Saddle Horse or "Mangalarga Marchador" with one case each. Males were more affected $(69 / 114)$ than females $(45 / 114)$. The horses had a median age of 10-years old and a mean age of 10.9-years old, with an age range of 3-days old to 35-years old. The frequency of diagnosis, as well as information regarding the sex, age range, mean and median age of the affected animals, according to each category, is presented in Table 1.

\section{Gastric dilation}

Grossly, the stomach was distended by moderate to large amounts of liquid and, often, fetid content, which in 21 cases caused a tearing of the stomach wall at the greater curvature. This led to stomach rupture, which was characterized by small to large amounts of feed content released into the abdominal cavity causing peritonitis (Fig.1A-B). In addition, the edges of the rupture were reddened, while frequently the serosa was lacerated, with adjacent hemorrhages, which dissected the muscular layer (Fig.1C). The main predisposing factor related to this condition was alimentary overload $(17 / 27)$ by corn $(10 / 17)$, grains $(3 / 17)$, or both $(4 / 17)$. Other lesions frequently observed in these horses were gastric ulcers $(8 / 27)$ and poor dentition $(5 / 27)$.

\section{Intestinal volvulus}

Intestinal volvulus was diagnosed in 27 horses, and the small intestine (mainly jejunum and ileum) and large intestine were involved in 14 and 13 cases, respectively. Of these 13 cases, the entire large colon and cecum were rotated in five cases, the large colon in three cases, the left dorsal and ventral colon in three cases, and only the cecum in two cases. Grossly, independently of the affected tissue, there was intestinal ischemia with reddened to deep black-red serosa of the compromised portion (Fig.1D-E), as well as moderate to severe luminal distension and diffusely red mucosae (Fig.1F). The small intestinal contents were reddish and liquid (14/14),

Table 1. Frequency of diagnosis of noninfectious diseases of the gastrointestinal tract in horses, as well as information regarding the sex, age range, mean and median age of the affected animals

\begin{tabular}{lcccc}
\hline \multicolumn{1}{c}{ Categories } & Frequency & Sex (M:F) & Age range & Mean/median age (y) \\
\hline Gastric dilation & $23.7 \%$ & $20: 7$ & $3 \mathrm{~m}-26 \mathrm{y}$ & $10.6 / 11$ \\
Volvulus & $23.7 \%$ & $13: 14$ & $1.5 \mathrm{~m}-35 \mathrm{y}$ & $9 / 8$ \\
Enterolithiasis & $17.5 \%$ & $13: 7$ & $5 \mathrm{y}-18 \mathrm{y}$ & $10.3 / 10$ \\
Rectal (colonic) perforation & $13.2 \%$ & $6: 9$ & $2 \mathrm{~m}-20 \mathrm{y}$ & $10.5 / 12$ \\
Impactions & $8.8 \%$ & $6: 4$ & $2 \mathrm{y}-25 \mathrm{y}$ & $11.1 / 10$ \\
Incarcerations or hernias & $5.3 \%$ & $5: 1$ & $5 \mathrm{y}-15 \mathrm{y}$ & $11 / 12$ \\
Intussusception & $3.5 \%$ & $4: 0$ & $3 \mathrm{~d}-8 \mathrm{y}$ & $2 / 0.04$
\end{tabular}

$\mathrm{M}=$ male, $\mathrm{F}=$ female, $\mathrm{d}=$ days old, $\mathrm{y}=$ years old $\mathrm{m}=$ months old . 
while the large intestinal contents were frequently dry and impacted (5/13). Other secondary gastrointestinal changes included secondary gastric impaction in three cases, and ruptures with peritonitis in two cases. In 11 cases, single or multiple predisposing factors per horse were identified: poor dentition in four cases, previous hospitalization/surgery in three, alimentary overload in three, feed changes in two, and recurrent colic in one case.
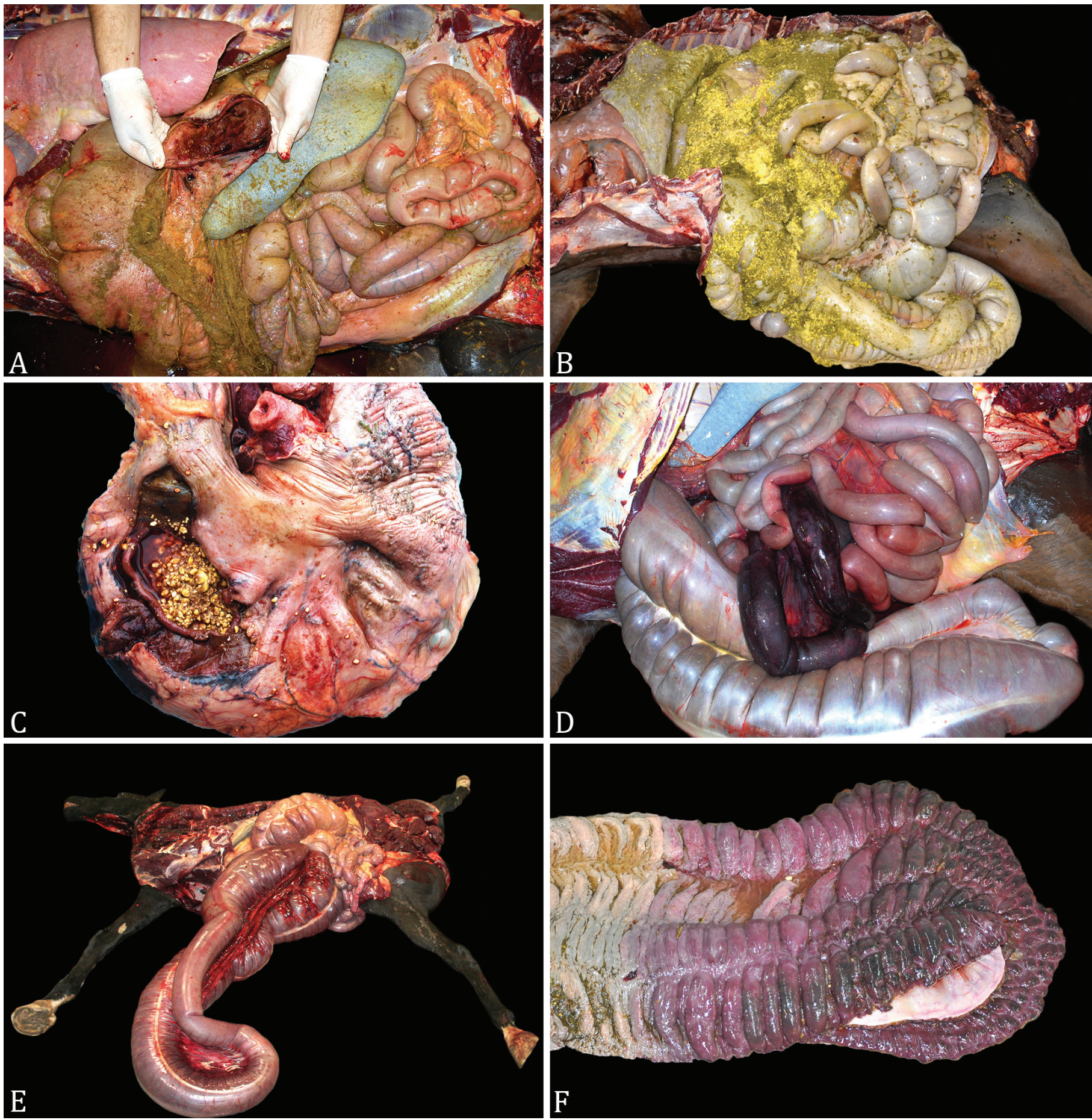

Fig.1. Gastric dilation and intestinal volvulus in horses in Southern Brazil. (A-B) Gastric dilation. Rupture of the stomach wall at the greater curvature with reddened edges and release of small to large amounts of feed content into the abdominal cavity, causing peritonitis. (C) The serosa of the stomach at the greater curvature was lacerated, with adjacent hemorrhages, and the muscular layer was dissected. (D) Intestinal volvulus. A segment of the small intestine twisted around its mesenteric axis, which caused intestinal ischemia, with deep black-red serosa of this segment. (E) The large colon had a $360^{\circ}$ twist (volvulus) which caused complete intestinal ischemia with diffusely dark-red serosa. (F) The left large colon (both ventral and dorsal) mucosa was diffusely reddish due to left large colon volvulus. 


\section{Enterolithiasis}

Enterolithiasis was the cause of death in 20 horses, leading to partial or complete intestinal obstruction in all cases. Enterolithiasis was followed by visceral perforation and peritonitis (11/20), as well as cecocolic impaction $(6 / 20)$, and secondary gastric dilation $(5 / 20)$. The right dorsal colon was the most affected segment (nine cases) (Fig.2A), followed by the transverse colon in four cases (Fig.2B), small
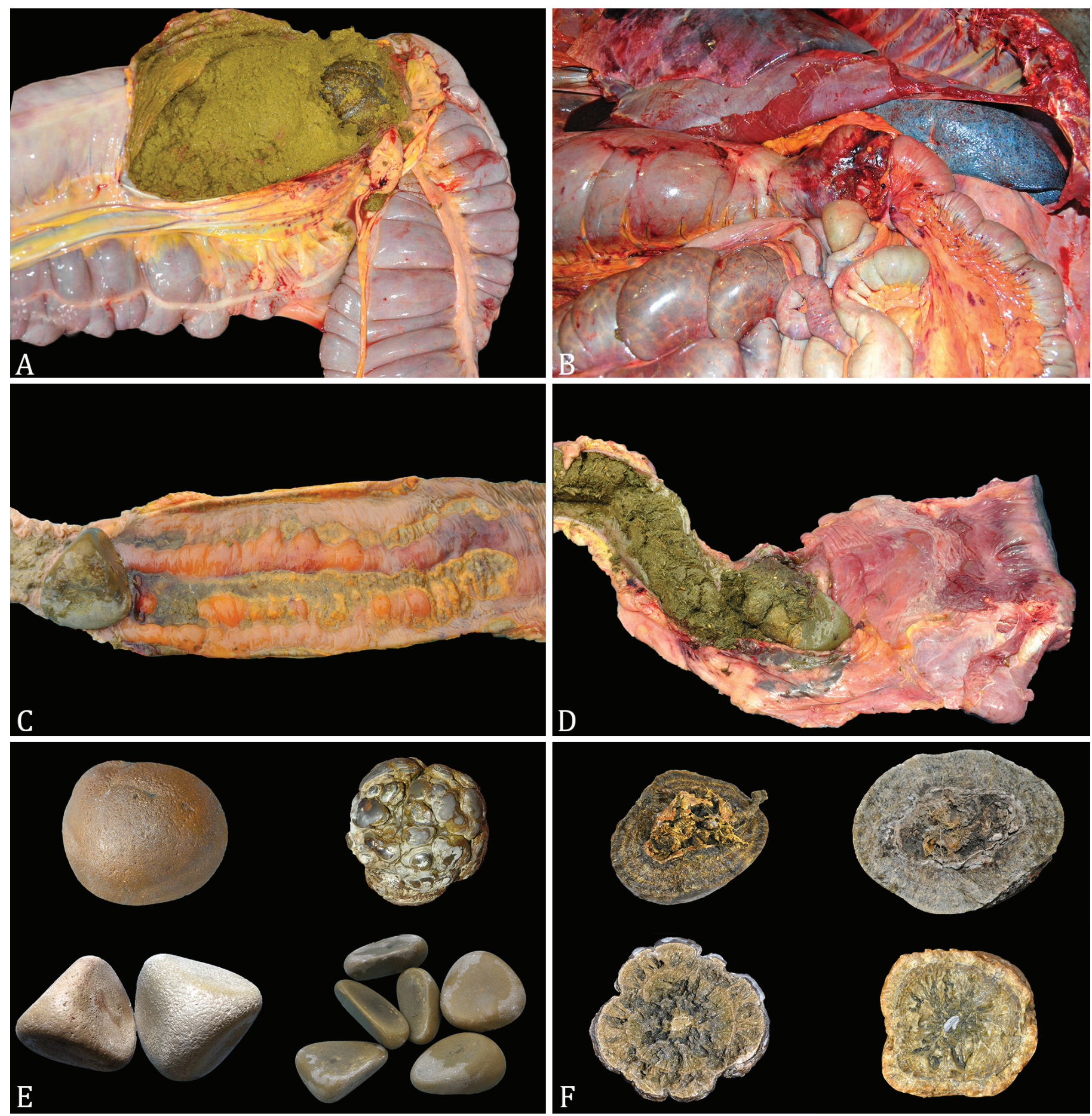

Fig. 2. Enterolithiasis in horses in Southern Brazil. (A) A rounded enterolith partially obstructed the lumen of the right dorsal large colon, and led to secondary anterior large colon impaction. (B) The transverse colon was another common location for enteroliths, as observed in this case, where it completely obstructed the lumen of the organ. (C) This pyramidal to flattened enterolith obstructed the final segment of the small colon, as well as it caused a severe focally extensive ulcer at the mucosa while it was moved by the guts. (D) This flattened enterolith was located at the rectum, where it caused a complete obstruction, in addition to secondary anterior impaction. (E) Clockwise, beginning at the top left corner, concretions were rounded, irregular, and flattened to pyramidal. (F) Clockwise, beginning at the top left corner, the enteroliths had concentric layers centered on rope (two cases), wire, and stone. 
colon and right dorsal colon simultaneously in three cases (perforation of the small colon was the cause of death), small colon in two cases (Fig.2C), and rectum and right dorsal colon simultaneously in two cases (rectal perforation was the cause of death; Fig 2D). Enteroliths varied in size, being smaller than $10 \mathrm{~cm}$ in diameter $(11 / 20)$ or larger than $10.1 \mathrm{~cm}$ in diameter $(9 / 20)$. These concretions were mostly single (11/20), but also multiple (9/20) per horse, with varying shapes (Fig.2E): rounded (13), irregular (7), pyramidal to flattened (4), and elongated (1). On the cut surface, some enteroliths exhibited concentric layers centered on a nidus: rope in seven cases, stone in two cases, and wire in one case (Fig.2F).

\section{Rectal (colonic) perforation}

Rectal (colonic) perforation was diagnosed in 15 cases, with involvement of the rectum in ten cases, transition between rectum and small colon in four cases, and small colon in one case. Grossly, these organs had focally extensive transmural tearing, associated with reddened borders, and retroperitoneal to diffuse peritonitis (Fig.3A-B). Iatrogenic injuries were the most common (11/15) causes, with colic related palpation in six cases (males and females) and reproductive tract palpation in five cases (only females), followed by one case of perforation that occurred after natural mating in a mare. In three cases, the clinical history was insufficient to establish a possible cause for the perforation.

\section{Impactions}

Impactions were diagnosed in ten cases, of which seven affected the large colon, two affected the cecum, and one affected the stomach. Grossly, cecocolonic impactions were caused by large amounts of impacted and dry content (6/9; Fig.3C), variable amounts of sand (2/9; Fig.3D), or plastic material within the lumen (1/9), while gastric impaction was caused solely by large amounts of impacted and dry ingesta, with a concomitant severe distal esophageal muscle hypertrophy. Locations affected within the large colon varied greatly from flexures (Fig.3E) to the entire organ. Other gastrointestinal lesions associated with cecocolonic impactions included intestinal rupture and peritonitis (3/9), as well as secondary gastric impaction (3/9). Predisposing factors included previous colic surgery (four cases), poor dentition (three cases; Fig.3F), water deprivation (three cases), dehydration (two cases), and anti-inflammatory treatment in one case. The horse affected by gastric impaction was found in a ditch without any food or water supply.

\section{Incarcerations}

Incarcerations or hernias were detected in six cases, of which two consisted of inguinoscrotal hernias (Fig.4A), other two of small intestine entrapment by a mesenteric failure, and two cases of diaphragmatic hernia and umbilical eventration (Fig.4B). Grossly, the small intestine was involved in five cases, and the large colon was involved in one case (diaphragmatic hernia). In all cases, the organs were constricted by a hernial ring, which led to intestinal ischemia with reddened to dark-red serosa. The intestinal contents were liquid and red. In the case of diaphragmatic hernia, the large colon was ruptured within the thoracic cavity. Predisposing factors included previous surgeries (two cases of small intestine entrapment within a mesenteric failure), and patent inguinal ring in one case.

\section{Intussusception}

Intussusception was diagnosed in four cases, of which three involved the small intestine (two in the jejunojejunum and one in the jejunoileum), while the other involved the ileocecum (Fig.4C-D). Three cases occurred in foals and were associated with lack of colostrum intake and concomitant pneumonia, while the other case occurred in an eight-year-old horse with poor dentition. In all cases, grossly, a segment of the small intestine slipped (intussusceptum) into another portion of the small/large intestine (intussuscipiens), causing a focal area of luminal obstruction and ischemia, with the intussusceptum presenting a diffuse deep black-red discoloration.

\section{other causes}

Other causes of noninfectious diseases of the gastrointestinal tract included two cases of left dorsal displacement of the colon, one case of extrinsic obstruction of the small intestine, one case of intrinsic obstruction at the jejunum, and one case of primary intestinal adenocarcinoma. The extrinsic obstruction of the small intestine was caused by foreign material (surgical dressing that led to fibrous adhesions between intestinal loops), and the intrinsic obstruction was caused by a linear foreign body (rope) with complete obstruction of the intestinal lumen. The neoplasm was composed by multifocal firm whitish masses $(6 \times 4 \times 3 \mathrm{~cm})$, which partially occluded the intestinal lumen, and was also associated with multifocal areas of intestinal stenosis. On the cut surface, it had a friable aspect (Fig.4E). In addition, the mesenteric lymph node was enlarged and firm. Histologically, there was an unencapsulated neoplastic proliferation of epithelial cuboidal cells arranged in tubules and papillae, occasionally filled by a faint basophilic content, extending from the mucosa into the internal muscular layer (suggestive of intestinal papillary adenocarcinoma). Additionally, the neoplastic cells were intermixed with a severe desmoplastic reaction (Fig.4F), inflammatory infiltrate of lymphocytes, and multifocal areas of necrosis. These cells were also observed within lymphatic vessels and within the mesenteric lymph node.

\section{DISCUSSION}

The diagnosis of the cases of the present study was obtained mainly by an association of the epidemiological and gross findings. Histological findings were restricted to the neoplasm case in order to obtain a differential diagnosis to other tumoral conditions, such as pythiosis (Uzal et al. 2016). Noninfectious gastrointestinal diseases were related to the cause of death mostly in adult horses with a median age of 10 -years old. This is similar to the median age of horses submitted to colic surgeries (8.5-years old) in a retrospective study conducted in Finland (Immonen et al. 2017) and in South Africa (Voigt et al. 2009), and it is equal to another investigation that evaluated the survival and complication rates of 300 horses submitted to surgical treatment of colic (Mair \& Smith 2005a). Regarding the affected breeds, there was an overrepresentation of mixed breeds and Criollo breed, that accounted for $76.8 \%$ of the cases, which may be a simple 
reflection of the horse population in Rio Grande do Sul state, as well as of the population examined at the hospital.

Volvulus of the small and large intestines and primary gastric dilation were the most common diagnoses in this work. This is distinct from that observed in a previous study, in which gastric dilation was the fourth leading cause of death related to the alimentary system in the same state (Pierezan et al. 2009), but similar to another investigation conducted in horses previously submitted to celiotomy, of which $11 \%$ of the deaths were linked to gastric rupture (Todhunter et al. 1986). Gastric dilation is often considered to be secondary to obstruction of the stomach, small bowel, or of colic with
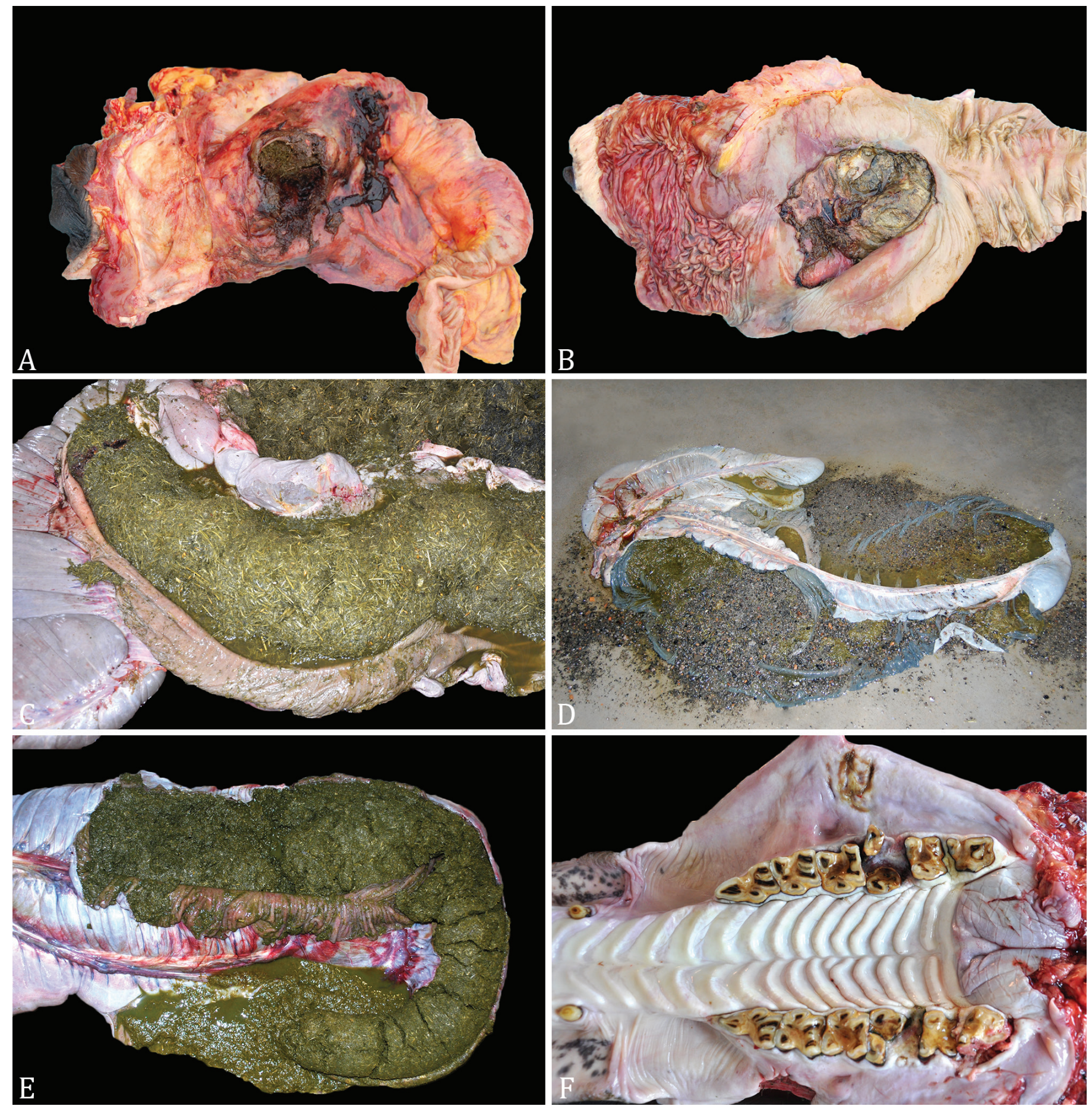

Fig. 3. Rectal (colonic) perforation and cecocolonic impaction in horses in Southern Brazil. (A) The rectum displays a focally extensive area of rupture characterized by transmural tearing, associated with reddened borders. (B) The mucosa of this ruptured area was severely ulcerated and covered by large amounts of fibrin and feces. (C) Impaction of the right ventral large colon by large amounts of dry contents. (D) Impaction was also caused by variable amounts of sand material within the lumen of the large colon. (E) Locations affected within the large colon were variable, as in this case, wherein the pelvic flexure was involved. (F) Poor dentition was a common predisposing factor to the development of impactions in horses, with shallow or absent maxillary teeth. 
adynamic (paralytic) ileus, which frequently follows abdominal surgery, especially when the intestines are roughly handled or traumatized (Uzal et al. 2016). Nonetheless, all cases of the present study were characterized as primary because of the absence of other gastrointestinal disturbances and to the identification of predisposing factors. Alimentary overload was the most common predisposing factor, wherein excess of corn, grain or both in the horse's diet were commonly detected. In addition, other associated findings included gastric ulcers, which in horses are often incidental findings
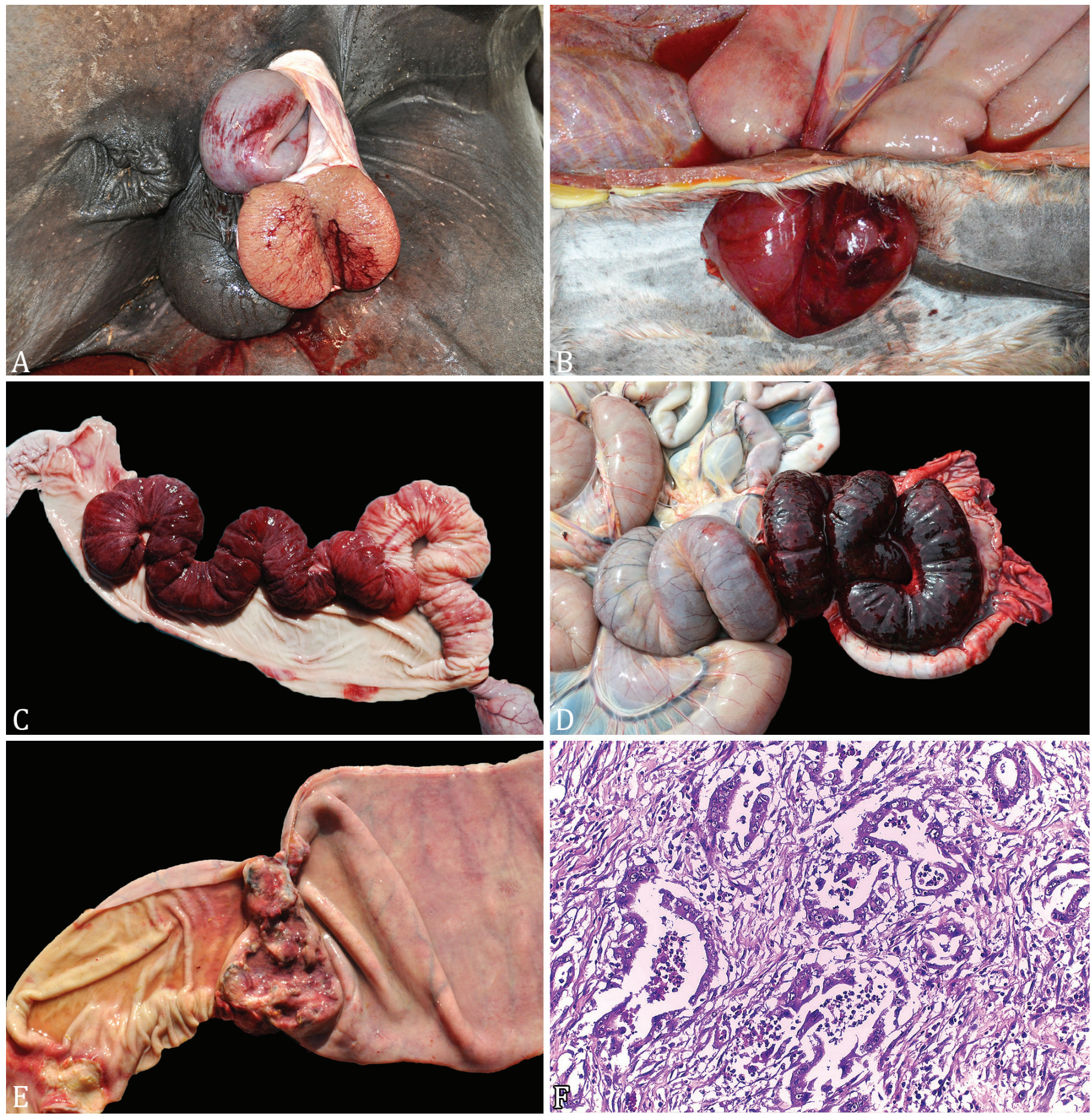

Fig. 4. Incarcerations or hernias, intussusceptions, and neoplasms in horses in Southern Brazil. (A) A segment of the small intestine has passed through the inguinal canal and reached the scrotum, where these intestinal loops were constricted and presented a reddened serosa. (B) Umbilical eventration of a small bowel segment caused intestinal ischemia with dark-red serosa. (C-D) Small intestine intussusception characterized by passage of an intussusceptum into an intussuscipiens, with the intussusceptum presenting a diffuse deep black-red discoloration. (E) A focal whitish and friable mass $(6 \times 4 \times 3 \mathrm{~cm})$ partially occluded the intestinal lumen. (F) Histologically, this mass was composed by a neoplastic proliferation of epithelial cuboidal cells arranged in tubules and papillae extending into the muscular layer, often intermixed with desmoplastic reaction. HE, obj.20x. 
at the necropsy, but may also be rarely related to perforation (Winfield \& Dechant 2015, Uzal et al. 2016). Nevertheless, gastric rupture and subsequent peritonitis were the most common pathological pictures observed in association with primary gastric dilation, unlike previous studies (Pierezan et al. 2009). Diffuse peritonitis in horses is often acute and fatal, as observed, owing to the small omentum of this species, which is probably related to the poor capacity of healing contaminated areas (Uzal et al. 2016). Grossly, all cases were differentiated from postmortem lesions based on the reddened edges at the ruptured sites at the greater curvature, which is the most common gastric rupture location in horses (Winfield \& Dechant 2015). Moreover, the lesions seemed to begin at the serosa, which was frequently stretched, as has been previously described in gastric ruptures, wherein, generally, the gastric seromuscular tears are larger than the mucosal tears, indicating that the seromuscular layer is weakened first (Todhunter et al. 1986).

Mesenteric volvulus of the small intestines, also referred to as mesenteric torsion, occurs frequently in species with a long small intestinal tract, such as in horses (Pierezan et al. 2009, Buergelt \& Del Piero 2014). Moreover, in horses, strangulating obstructions of the small bowel are associated with reduced short-term survival rates after surgery (Mair \& Smith 2005a). Similarly, in the present investigation, small intestine volvulus was the most common pathological presentation of volvulus and affected mainly adults older than six-years old, in accordance to a previous study in which small intestine volvulus occurred in animals with a median age of five-years old (Stephen et al. 2004). Furthermore, in horses, the large colon and cecum are predisposed to volvulus owing to the lack of mesenteric anchorage and potential mobility of the large intestines within the abdominal cavity (Uzal et al. 2016), as frequently observed in the present work, in which the large intestine was almost equally affected by volvulus as the small intestine. Colon volvulus has been considered to be one of the most painful and fatal cause of colic in the horse (Suthers et al. 2013), in addition to a relatively common complication of previous colic surgeries leading to relaparotomy (Mair \& Smith 2005c), but in the present investigation this predisposing factor was not identified. It is estimated that between 10 to $20 \%$ of horses submitted to exploratory celiotomy present large colon volvulus (Suthers et al. 2013), similarly to the current study in which large intestine volvulus represented $11.4 \%$ of the total of causes of death (13/114). Grossly, small and large intestinal volvulus shared similar gross aspects as well as similar secondary gastrointestinal changes, in accordance to that previously described (Uzal et al. 2016).

Enterolithiasis has been previously identified in $15.1 \%$ of horses presenting for colic and in $27.5 \%$ of patients undergoing celiotomy for colic treatment (Hassel et al. 1999), while Corrêa et al. (2006) found that approximately $15.4 \%$ of the horses submitted to surgical abdominal procedures had enterolithiasis, which is very similar to the frequency of causes of death observed in the current work (17.5\%). This reinforces that this may be an important condition in horses with clinical signs of colic in Southern Brazil. Enteroliths are mineral concretions (calculi) usually formed in the ampulla coli of the right dorsal colon (Hassel 2002), and are composed by distinct amounts of magnesium, ammonium, and phosphate, which are often arranged in concentric lamellae around a central nidus (Uzal et al. 2016), as in the present study. These concretions are most commonly solitary (Hassel et al. 1999), as in most of the cases in this work (55\%), but may also be multiple within the guts. Enterolithiasis is a common cause of obstructive colic in horses with records dating up to 140 years (Hassel 2002). It occurs when the concretion passes through the intestinal tract until it causes intestinal obstruction with subsequent luminal distention, mucosal necrosis, and, possibly, perforation of the guts (Uzal et al. 2016). This was often observed in the current study as all enteroliths were partially or completely obstructing the intestinal lumen, whereas in 55\% (11/20) of the cases there was also intestinal perforation and peritonitis, which is distinct from a previous investigation that reported only $15 \%$ of intestinal rupture in association with enterolithiasis (Hassel et al. 1999). This difference probably occurred due to delay on the decision by the clinicians to perform a celiotomy in the present cases.

Common locations for the enteroliths to become entrapped are the transition into the transverse colon (Buergelt \& Del Piero 2014), right dorsal colon, and descending colon (small colon) (Hassel et al. 1999, Hassel 2002), similarly to the present study in which the right dorsal large colon and the transverse colon were the most common locations. Moreover, an uncommon location (rectum) was also affected, while the pelvic flexure was not affected, suggesting that this is not a common location, unlike previously described (Buergelt \& Del Piero 2014). Similar to other studies (Hassel et al. 1999, Pierezan et al. 2009), adult horses with a mean and median age of 10.3 and 10-years old, respectively, were most commonly affected. This was expected as the pathogenesis of enterolith formation is longstanding owing to the fact that it depends on many factors: salts, a nidus for precipitation of triple phosphates, and some degree of intestinal hypomotility (Buergelt \& Del Piero 2014). In vivo diagnosis of enterolithiasis relies mainly on abdominal radiography, rectum palpation, and/or exploratory laparotomy. Still, abdominal radiographs may fail if the enterolith is located in the small colon, as well as palpation per rectum may provide limited information mainly because of the size of the examined horse, with enteroliths located at the terminal right dorsal colon being rarely detected (Hassel 2002). This reinforces that concretions located at the right dorsal colon, transverse colon, and small colon, such as in most of the cases of this work, may be related to poor prognosis if not properly detected early. Furthermore, smaller enteroliths, such as the ones involving the small colon and rectum in this study, are potentially more pathogenic than similar concretions present in the large dorsal colon, as they may obstruct the intestinal lumen (Hassel et al. 2008), while larger enteroliths are always contained within the right dorsal colon (Hassel et al. 1999). Several different shapes of enteroliths may occur in horses, but most commonly these are spherical or tetrahedral, in which the latter is frequently multiple (Hassel 2002). In the current investigation, most were rounded to spherical and often irregularly shaped. In six cases, poor dentition was observed and interpreted as a possible consequence of imbalanced diets, similarly to a previous study in Criollo horses which reported $56.25 \%$ of dentition problems occurring in association with enterolithiasis (Santos et al. 2017).

Rectal (colonic) perforation in horses are job-related risks for equine veterinarians, as accidental iatrogenic events may 
occur, such as obstetric interventions and/or rectal palpation (Buergelt \& Del Piero 2014, McMaster et al. 2015, Uzal et al. 2016). This was observed in the present study, wherein iatrogenic injuries were reported in $73.3 \%$ of the cases $(11 / 15)$. Most perforation-related tears occur 25 to $30 \mathrm{~cm}$ away from the anus, involve the rectum mainly at the dorsal aspect (Uzal et al. 2016), and are, thus, difficult to be surgically accessed (McMaster et al. 2015). However, in four cases of the current work, the tears/perforations were located at the limit between the rectum and small colon, and at the small colon in another horse. Therefore, a better nomenclature for these would be rectal-colonic perforation in cases wherein the boundaries between these two organs are not clear. Rectal tears may be classified into grades 1 to 4 based on the extent of disruption, with full-thickness rupture observed only in grade 4 (Watkins et al. 1989), as all the cases of this study would be classified. Moreover, only $6 \%$ of the horses with grade 4 lesions survive (McMaster et al. 2015), which is mainly because of secondary peritonitis. This was a constant finding associated with these lesions in this investigation, occurring either as a located or disseminated lesion. As expected based on previous studies (Claes et al. 2008), females were mostly affected by injuries related to reproductive tract palpation. Horses older than nine-years old, similarly to the ones of the current study, are more predisposed to these perforations (Claes et al. 2008), as the reproductive tract becomes more pendulous at these ages and the frequency of palpation in subfertile older mares is increased (LeBlanc et al. 1998). Moreover, colic related palpation affected both males and females, but especially males, which probably occurred because stallions or geldings are less used to palpation per rectum than mares, and other factors, such as restless behavior, small rectum, inadequate restraint, application of inadequate amounts of lubricants and absence of spasmolytic drugs, may have played a role in these cases (Stauffer 1981). Interestingly, a case of rectal perforation following natural mating in a mare was detected, which appears to be an unusual presentation, that was not observed in a previous investigation of 99 cases of rectal perforation in the USA (Claes et al. 2008), but was previously reported in a mare following accidental penetration of a stallion's penis into the rectum (Arnold et al. 1978).

Large intestine and stomach impaction was the fifth most common category of gastrointestinal noninfectious disease detected as the cause of death in horses of the present work, which is distinct from previous clinical studies that identified impactions as the most common causes of colic (Abutarbush et al. 2006, Voigt et al. 2009). Indeed, this difference may be based on the fact that secondary impactions are often clinically detected without proper identification of the primary cause. Predisposing factors to this condition in horses are water deprivation, poor dentition, and dietary changes (Uzal et al. 2016), as observed in the current study. Dental problems were evidenced in three cases, but, still, a previous work was not able to establish an association between dental pathology, fecal particle size, and impaction colic in horses (Gunnarsdottir et al. 2014). Furthermore, another important predisposing factor identified was previous colic surgery in four cases. Postoperative colic during the first year after surgery may reach an incidence of $20 \%$ in horses (Immonen et al. 2017), and these surgeries may act by modifying the colonic or cecal peristalsis, causing abnormal motility (Uzal et al. 2016). In horses, this pathogenesis is usually related to adynamic or paralytic ileus when intestines are not properly handled at surgery (Uzal et al. 2016), but may also apply to the present cecocolonic impaction cases. Unlike previous investigations, impactions affected not only locations where the lumen was narrowed, such as the pelvic flexure and the transverse/small colon (Uzal et al. 2016), but also the entire large colon and cecum. In these cases, probably the association of predisposing factors, which were frequently multiple per horse, worsened the condition.

Sand impaction was detected in two cases and is commonly related to horses grazing in poorly covered sandy soils (Uzal et al. 2016). The ingested sand tends to settle down within the cecum and the ventral large colon, rendering these organs susceptible to rupture (Buergelt \& Del Piero 2014), as occurred in one of the cases of the present study. Nonetheless, the mortality rate for horses with sand impaction is reported to be low, as observed in this work in which a low frequency was detected (two cases), and early surgical intervention may provide a good prognosis (Granot et al. 2008). Furthermore, the stomach was involved in one case of primary impaction, which is a rare cause of colic in horses (Bird et al. 2012), and in this situation it was caused by inadequate water supply, since the horse was found in a ditch without any food or water available for three days. Primary gastric impactions are usually characterized by large quantities of ingesta (15$35 \mathrm{~kg}$ ) associated with gross thickening of the muscle layers of the stomach wall, in addition to variable thickening of the pylorus and hypertrophy of the distal esophageal muscles (Bird et al. 2012), which was observed grossly in this case.

Incarcerations or hernias occurred mainly as internal and external hernias, such as inguinoscrotal and diaphragmatic, but also as internal failures of the mesentery and a case of eventration. Grossly, these lesions were typical of intestinal ischemia and infarction (Uzal et al. 2016), exhibiting reddened to dark-red serosa. The pathogenesis of this condition may be related to fixation of the hernial/entrapped contents within a location, which may be followed by distention of the viscera with accumulated gas or ingesta, and later the lesion becomes nonreducible (Uzal et al. 2016). Inguinal hernias may evolve to scrotal hernia when the herniated pass down the inguinal canal. These lesions are usually observed in foals because the inguinal ring tends to close as the animal grows up (Uzal et al. 2016). Unlike that, two cases of inguinoscrotal hernias were detected in adult horses in the present investigation, and a patent inguinal ring-opening was detected in one of these. Moreover, an umbilical eventration was observed in an adult horse, but it could have resulted from a rare enterocutaneous fistula related to an umbilical hernia (Uzal et al. 2016). Another interesting finding were two cases of small intestine entrapment by a mesenteric failure, which were most likely related to previous surgeries that caused tissue gaps within the mesentery, allowing the small intestinal loops to slip into this failure and become entrapped (Buergelt \& Del Piero 2014).

Intussusceptions were not frequently detected in this study, corresponding to only $3.5 \%$ of the diagnosis, as was observed in another study, which pointed out a prevalence of $8.7 \%$ of intussusceptions in horses undergoing laparotomy owing to abdominal pain (Edwards 1986). This condition is usually related to preceding intestinal hypermotility or endoparasitism (Buergelt \& Del Piero 2014), as well as it may be associated 
with previous intestinal surgery, enteritis, and tumors (Uzal et al. 2016). In two of the present cases, decreased intake of colostrum and concomitant pneumonia were identified as predisposing factors, and probably resulted in hypermotility of the guts. Still, in horses ileocecal or cecocolic intussusceptions are most commonly detected (Bell \& Textor 2010, Buergelt \& Del Piero 2014), while in this investigation jejunojejunal and jejunoileal intussusceptions were more frequent. This difference probably occurred because of the lower age of the animals affected, with a median age of 0.04-years old (which corresponds to almost 15-days old), when compared to another study that investigated cecal intussusceptions in horses with a median age of 14.5-months old (Bell \& Textor 2010). Grossly, intussusception may present as a simple obstruction if mural blood flow is preserved, or as a necrotic lesion when there is occlusion of the blood flow (Nelson \& Brounts 2012). This second pattern was the most commonly observed in the current work, with ischemic lesions affecting the intussusceptum, which probably occurs in most severe cases wherein this condition is related to the cause of death of horses.

Intestinal neoplasms are rare in horses (Munday et al. 2017), and are usually mesenchymal, mainly represented by fibrosarcomas, leiomyosarcomas, and gastrointestinal stromal tumors (GIST) (Buergelt \& Del Piero 2014), additionally to lymphoma and adenocarcinoma (Taylor et al. 2006). However, in this investigation a primary intestinal adenocarcinoma was detected, and, similarly to that previously described (Uzal et al. 2016), it represented less than 1\% of the cases. These neoplasms usually involve the small intestines of adult horses and most of them invade the intestine wall, rarely causing complete obstruction of the lumen (Taylor et al. 2006), similarly to the one observed in the present work. Histologically, neoplastic cells tend to be well differentiated and intermixed with marked fibrous metaplasia (desmoplastic reaction) (Munday et al. 2017), as in this case. Another finding of this investigation was one case of extrinsic obstruction of the small intestine caused by a foreign material that led to focal adhesion in a similar manner that previously reported in long-term complications of previous colic surgeries in horses (Mair \& Smith 2005b). Adhesions become a clinical problem only when they mature into fibrous adhesions, which may compress or anatomically distort the intestine, causing an obstruction (Mair \& Smith 2005b), which occurred in this case.

\section{CONCLUSIONS}

Noninfectious diseases of the gastrointestinal tract are major causes of colic and death of horses in general, and are the main diseases affecting the alimentary system in this species. Gastric dilation and volvulus were the most common conditions. Enterolithiasis was the third most common diagnosis and visceral perforation with peritonitis frequently occured. Rectal (colonic) perforation was most commonly related to iatrogenic injuries associated with colic related and reproductive tract palpation, affecting more males and females, respectively.

Impactions affected mostly the large colon and cecum, with previous colic surgery, poor dentition, water deprivation, and dehydration identified as important predisposing factors.

Incarcerations were mostly related to hernias, mesenteric failures, and eventration.
Intussusception was observed mainly in the small intestine of foals and it was often related to other concomitant diseases.

Other causes were less common and included a multifocal primary intestinal papillary adenocarcinoma causing a partial occlusion of the intestinal lumen, as well as multifocal areas of stenosis.

Epidemiological and gross lesions are essential to obtain a final diagnosis of these conditions.

Funding sources.- We thank the "Conselho Nacional de Desenvolvimento Científico e Tecnológico" (CNPq), and the "Coordenação de Aperfeiçoamento de Pessoal de Nível Superior" (CAPES) for supporting this study.

Conflict of interest statement.- The authors have no competing interests.

Animal welfare/ethical statement.- We authors of the article entitled "Epidemiological and pathological aspects of noninfectious diseases of the gastrointestinal tract in 114 horses in Southern Brazil" declared, for all due purposes, that the project that gave rise to the present data of this manuscript was submitted to the Research Commission of the "Universidade Federal do Rio Grande do Sul" (UFRGS) for evaluation, and was approved under the number 33501 on December 7th, 2017.

\section{REFERENCES}

Abutarbush S.M., Carmalt J.L. \& Shoemaker R.W. 2006. Causes of gastrointestinal colic in horses in western Canada: 604 cases (1992-2002). Can. Vet. J. 46(9):800-805. <PMid:16231649>

Arnold J.S., Meagher D.M. \& Lohse C.L. 1978. Rectal tears in the horse. J. Equine Med. Surg. 2:55-61.

Baker J.R. \& Ellis C.E. 1981. A survey of post mortem findings in 480 horses 1958 to 1980: causes of death. Equine Vet. J. 13(1):43-46. <http://dx.doi. org/ 10.1111/j.2042-3306.1981.tb03448.x><PMid:7238480>

Bell R.J.W. \& Textor J.A. 2010. Caecal intussusceptions in horses: a New Zealand perspective. Aust. Vet. J. 88(7):272-276. <http://dx.doi. org/10.1111/j.1751-0813.2010.00591.x ><PMid:20579034>

Bird A.R., Knowles E.J., Sherlock C.E., Pearson G.R. \& Mair T.S. 2012. The clinical and pathological features of gastric impaction in twelve horses. Equine Vet. J. 44(43):105-110. <http://dx.doi.org/10.1111/j.2042-3306.2012.00674. $\mathrm{x}><$ PMid:23447888>

Bland S.D. 2016. Equine colic: a review of the equine hindgut and colic. Vet. Sci. Develop. 6(6223):48-52. <http://dx.doi.org/10.4081/vsd.2016.6223>

Buergelt C.D. \& Del Piero F. 2014. Color Atlas of Equine Pathology. John Wiley and Sons, Ames, p.115-116.

Claes A., Ball B.A., Brown J.A. \& Kass P.H. 2008. Evaluation of risk factors, management, and outcome associated with rectal tears in horses: 99 cases (1985-2006). J. Am. Vet. Med. Assoc. 233(10):1605-1609.<http://dx.doi. org/10.2460/javma.233.10.1605> <PMid:19014297>

Corrêa R.R., Zoppa A.L.V., Fernandes W.R., Baccarin R.Y.A, Cruz R.S.F. \& Fantoni D.T. 2006. Estudo retrospectivo dos casos de enterolitíase e corpo estranho em intestino grosso de eqüinos, no período de janeiro de 1993 a janeiro de 2003. Braz. J. Vet. Res. Anim. Sci. 43(2):242-249.

Edwards G.B. 1986. Surgical management of intussusception in the horse. Equine Vet. J. 18(4):313-321.<http://dx.doi.org/10.1111/j.2042-3306.1986. tb03640.x><PMid:3758012>

Granot N., Milgram J., Bdolah-abram T., Shemesh I. \& Steinman A. 2008 Surgical management of sand colic impactions in horses: a retrospective study of 41 cases. Aust. Vet. J. 86(10):404-410. <http://dx.doi.org/10.1111/j.17510813.2008.00348.x > <PMid:18826513>

Gunnarsdottir H., Van der Stede Y., De Vlamynck C., Muurling F., De Clercq D., Van Loon G. \& Vlaminck L. 2014. Hospital-based study of dental pathology and faecal particle size distribution in horses with large colon impaction. 
Vet. J. 202:153-156. <http://dx.doi.org/10.1016/j.tvjl.2014.07.013> <PMid:25135337>

Hassel D.M. 2002. Enterolithiasis. Clin. Tech. Equine Pract. 1(3):143-147. <http://dx.doi.org/10.1053/ctep.2002.35576>

Hassel D.M., Aldridge B.M., Drake C.M. \& Snyder J.R. 2008. Evaluation of dietary and management risk factors for enterolithiasis among horses in California. Res. Vet. Sci. 85(3):476-480. <http://dx.doi.org/10.1016/j. rvsc.2008.03.001><PMid:18423503>

Hassel D.M., Langer D.L., Snyder J.R., Drake C.M., Goodell M.L. \& Wyle A. 1999. Evaluation of enterolithiasis in equids: 900 cases (1973-1996). J. Am. Vet. Med. Assoc. 214(2):233-237. <PMid:9926016>

Immonen I.A.M., Karikoski N., Mykkänen A., Niemelä T., Junnila J. \& Tulamo R.M. 2017. Long-term follow-up on recovery, return to use and sporting activity: a retrospective study of 236 operated colic horses in Finland (2006-2012). Acta Vet. Scand. 59(5):1-11. <http://dx.doi.org/10.1186/ s13028-016-0273-9><PMid:28057022>

LeBlanc M.M., Neuwirth L., Jones L., Cage C. \& Mauragis D. 1998. Differences in uterine position of reproductively normal mares and those with delayed uterine clearance detected with scintigraphy. Theriogenology 50(1):49-54. <http://dx.doi.org/10.1016/s0093-691x(98)00112-5><PMid:0734473>

Mair T.S. \& Smith L.J. 2005a. Survival and complication rates in 300 horses undergoing surgical treatment of colic. Part 1: Short-term survival following a single laparotomy. Equine Vet. J. 37(4):303-309. <http://dx.doi. org/10.2746/0425164054529364> <PMid:16028617>

Mair T.S. \& Smith L.J. 2005b. Survival and complication rates in 300 horses undergoing surgical treatment of colic. Part 3: Long-term complications and survival. Equine Vet. J. 37(4):310-314. <http://dx.doi. org/10.2746/0425164054529445><PMid:16028618>

Mair T.S. \& Smith L.J. 2005c. Survival and complication rates in 300 horses undergoing surgical treatment of colic. Part 4: Early (acute) relaparotomy. Equine Vet. J.37(4):315-318.<http://dx.doi.org/10.2746/0425164054529454> $<$ PMid:16028619>

Marcolongo-Pereira C., Estima-Silva P., Soares M.P., Sallis E.S.V., Grecco F.B., Raffi M.B., Fernandes C.G. \& Schild A.L. 2014. Equine diseases in Southern Brazil. Pesq. Vet. Bras. 34(3):205-210.<http://dx.doi.org/10.1590/S0100736X2014000300002>

McMaster M., Caldwell F., Schumacher J., McMaster J. \& Hanson R. 2015. A review of equine rectal tears and current methods of treatment. Equine Vet. Educ. 27(4):200-208. <http://dx.doi.org/10.1111/eve.12266>

Munday J.S., Lohr C.V. \& Kiupel M. 2017. Tumors of the alimentary tract, p.568. In: Meuten D.J. (Ed.), Tumors in Domestic Animals. 5th ed. Wiley Blackwell, New Jersey.

Nelson B.B. \& Brounts S.H. 2012. Intussusception in horses. Compend. Contin. Educ. Vet. 34(7):E4.

Pierezan F., Rissi D.R., Rech R.R., Fighera R.A., Brum J.S. \& Barros C.S.L. 2009. Necropsy findings related to the cause of death in 335 horses: 1968-2007.
Pesq. Vet. Bras. 29(3):275-280. <http://dx.doi.org/10.1590/S0100736X2009000300015>

Proudman C.J., Smith J.E., Edwards G.B. \& French N.P. 2002. Long-term survival of equine surgical colic cases. Part 1, patterns of mortality and morbidity. Equine Vet.J. 34(5):432-437.<http://dx.doi.org/10.2746/042516402776117845> $<$ PMid:12358043>

Santos A.C., Curcio B.R., Finger I.S., Castro Junior J. \& Nogueira C.E.W. 2017. Enterolithiasis in Crioulo horses. Acta Scient. Vet. 45(Supl.1):183.

Stauffer V.D. 1981. Equine rectal tears: a malpractice problem. J. Am. Vet. Med. Assoc. 178(8):798-799. <PMid:7275775>

Stephen J.O., Corley K.T.T, Johnston J.K. \& Pfeiffer D. 2004. Small intestinal volvulus in 115 horses: 1988-2000. Vet. Surg. 33(4):333-339. <http:// dx.doi.org/10.1111/j.1532-950X.2004.04048.x><PMid:15230835>

Suthers J.M., Pinchbeck G.L., Proudman C.J. \& Archer D.C. 2013. Survival of horses following strangulating large colon volvulus. Equine Vet. J. 45(2):219-223. <http://dx.doi.org/10.1111/j.2042-3306.2012.00620. $\mathrm{x}><$ PMid:22994687>

Taylor S.D., Pusterla N., Vaughan B., Whitcomb M.B. \& Wilson W.D. 2006. Intestinal neoplasia in horses. J. Vet. Intern. Med. 20(6):1429-1436. <http://dx.doi.org/10.1892/0891-6640(2006)20[1429:inih]2.0.co;2> $<$ PMid:17186861>

Tinker M.K., White N.A., Lessard P., Thatcher C.D., Pelzer K.D., Davis B. \& Carmel D.K. 1997. Prospective study of equine colic incidence and mortality. Equine Vet. J. 29(6):448-453. <http://dx.doi.org/10.1111/j.2042-3306.1997. tb03157.x><PMid:9413717>

Todhunter R.J., Erb H.N. \& Roth L. 1986. Gastric rupture in horses: a review of 54 cases. Equine Vet. J. 18(4):288-293. <http://dx.doi. org/10.1111/j.2042-3306.1986.tb03631.x ><PMid:3758007>

USDA 2017. Equine mortality in the United States, 2015. Center for Epidemiology and Animal Health, Veterinary Services, Animal and Plant Health Inspection Service (APHIS), United States Department of Agriculture (USDA). Available at <https://www.aphis.usda.gov/animal_health/nahms/ equine/downloads/equine15/Equine15_is_Mortality.pdf>.

Uzal F.A., Plattner B.L. \& Hostetter J.M. 2016. Alimentary system, p.1-257. In: Maxie M.G.(Ed.), Jubb, Kennedy, and Palmer's Pathology of Domestic Animals. Vol.2. 6th ed. Elsevier, St. Louis.

Voigt A., Saulez M.N., Donnellan C.M. \& Gummow B. 2009. Causes of gastrointestinal colic at an equine referral hospital in South Africa (19982007). Tydskr. S. Afr. Vet. Ver. 80(3):192-198. <http://dx.doi.org/10.4102/ jsava.v80i3.201 > <PMid:20169755>

Watkins J.P., Taylor T.S., Schumacher J., Taylor J.R. \& Gillis J.P. 1989. Rectal tears in the horse: an analysis of 35 cases. Equine Vet. J. 21(3):186-188. <http://dx.doi.org/10.1111/j.2042-3306.1989.tb02138.x><PMid:2731505>

Winfield L.S. \& Dechant J.E. 2015. Primary gastric rupture in 47 horses (1995-2011). Can. Vet. J. 56(9):953-958. <PMid:26345205> 